\title{
Article \\ Optimization of the Synthesis of Fungus-Mediated Bi-Metallic Ag-Cu Nanoparticles
}

\author{
Fuad Ameen
}

Citation: Ameen, F. Optimization of the Synthesis of Fungus-Mediated

Bi-Metallic Ag-Cu Nanoparticles. Appl. Sci. 2022, 12, 1384. https://doi.org/ 10.3390/app12031384

Academic Editors: Alexandru Mihai Grumezescu and Oana Gherasim

Received: 16 December 2021

Accepted: 26 January 2022

Published: 27 January 2022

Publisher's Note: MDPI stays neutral with regard to jurisdictional claims in published maps and institutional affiliations.

Copyright: (C) 2022 by the author. Licensee MDPI, Basel, Switzerland. This article is an open access article distributed under the terms and conditions of the Creative Commons Attribution (CC BY) license (https:// creativecommons.org/licenses/by/ $4.0 /)$.

\begin{abstract}
Department of Botany \& Microbiology, College of Science, King Saud University, Riyadh 11451, Saudi Arabia; fuadameen@ksu.edu.sa
\end{abstract}

\begin{abstract}
Bi-metallic nanoparticles (NPs) have appeared to be more efficient as antimicrobials than mono-metallic NPs. The fungus Aspergillus terreus-mediated synthesis of bi-metallic Ag-Cu NPs was optimized using response surface methodology (RSM) to reach the maximum yield of NPs. The optimal conditions were validated using ANOVA. The optimal conditions were $1.5 \mathrm{mM}$ total metal $(\mathrm{Ag}+\mathrm{Cu})$ concentration, $1.25 \mathrm{mg}$ fungal biomass, $350 \mathrm{~W}$ microwave power, and $15 \mathrm{~min}$ reaction time. The structure and shape of the synthesized NPs (mostly 20-30 nm) were characterized using several analytical tools. The biological activities of the synthesized NPs were assessed by studying their antioxidant, antibacterial, and cytotoxic activity in different NP concentrations. A dose-dependent response was observed in each test. Bi-metallic Ag-Cu NPs inhibited three clinically relevant human pathogens: Klebsiella pneumoniae, Enterobacter cloacae, and Pseudomonas aeruginosa. Escherichia coli, Enterococcus faecalis, and Staphylococcus aureus were inhibited less. The DPPH and hydrogen peroxide scavenging activities of the NPs were high, reaching 90\% scavenging. Ag-Cu NPs could be studied as antimicrobials in different applications. The optimization procedure using statistical analyses was successful in improving the yield of nanoparticles.
\end{abstract}

Keywords: bi-metallic nanoparticles; RSM; optimization; Ag-Cu; microwave power

\section{Introduction}

Nanotechnological solutions are increasingly developed to be used as antimicrobial agents in biomedicine. Physical and chemical techniques to produce nanoparticles (NPs) have largely been inserted with eco-friendly biological techniques [1,2]. Nowadays, nanotechnology offers eco-friendly solutions not only for biomedicine but for agriculture and the remediation of polluted environments [3-5].

The use of fungi in the synthesis of NPs has gained much attention recently. Fungi have been found to be efficient in reducing metal salts to NPs by producing proteins and catalysts that enable rapid synthesis [6,7]. Fungi are especially suitable due to their metal resistance and ability to accumulate metals [8]. Moreover, fungi-mediated NPs are of controlled size and morphology [9-13]. As a whole, the fungi-mediated synthesis of NPs offers a technology that can be scaled up to industrial needs.

Nanoparticles can be synthesized using one or more metals. Recent research has recognized the positive synergistic effects of the metals in bi-metallic NPs [14,15]. The shapes of bi-metallic NPs are diverse and the ratio of surface to volume is high compared to mono-metallic NPs [16]. Moreover, bi-metallic NPs have higher stability and activity than mono-metallic NPs $[17,18]$. Several combinations of metals such as Ag-Cu, Au-Pt, Co-Ni, Ag-Pd, and Fe-Pt have been presented [17-21]. Ag-Cu NPs have been reported for structural and thermal stability [19-21].

Various techniques to synthesize NPs have been studied. Recently, the advantage of microwave reactors in the synthesizing process has been presented [22,23]. The efficient penetration of microwaves enables the homogeneous, rapid heating of the materials. The 
use of microwaves produces a high yield of NPs and needs less time and chemicals. Thus, the microwave method fulfills the principles of green chemistry.

In the synthesizing process, many parameter values such as the microwave power, the amount of biomass used, the concentration of metals, and the reaction time must be chosen It is crucial, yet seldom carried out previously, to optimize the conditions by modeling. One method to optimize the conditions is response surface methodology (RSM) [3], which has also been taken into use in NP synthesis recently [24,25]. The advantage of optimizing the conditions is studying several parameters and choosing the best combination of the parameter values to gain the maximum yield of NPs.

The objectives of this study were to combine two novel aspects in nanoparticle research: to optimize the process parameters using statistical methods and to produce bi-metallic $\mathrm{Ag}-\mathrm{Cu}$ NPs that have high biological activities. Treatments to optimize four parameters of the NP synthesizing process were carried out. Then, tests to study the antimicrobial, antioxidant, and cytotoxic activities of the synthesized Ag-Cu NPs were carried out.

\section{Material and Methods}

\subsection{Synthesis of $\mathrm{Ag} / \mathrm{CuO} \mathrm{NPs}$}

The fungus Aspergillus terreus was isolated from the southern Red Sea coast, Saudi Arabia, as described by Ameen et al. [26]. The fungus was identified using molecular methods as described by [27].

To produce $\mathrm{Ag} / \mathrm{CuO}$ NPs, metal salts $\left(\mathrm{AgNO}_{3}\right.$ and $\left.\mathrm{CuNO}_{3}\right)$ and fungal biomass were mixed and kept in a microwave (MW) reactor under stirring for a specific time, as described by Cuevas et al. [28]. The parameter values were optimized and are described above. The final turbid or precipitate was collected and washed thrice to remove unwanted metal salts and biomass. The final pellet was calcinated at $450{ }^{\circ} \mathrm{C}$, and the purified NPs were stored in an airtight container.

\subsection{Experimental Design and Statistical Analysis}

An experiment using a single factor design was carried out. The experiment was carried out using the Box-Behnken experimental design [29]. A total of 27 treatments were carried out with the different process parameter values presented in Table S1 (Supplementary File). Response surface methodology (RSM) was used to optimize the parameter values, as described by [30]. The adequacy of the model was analyzed with ANOVA using Minitab (version 13) software. The significance level was set to $p<0.05$. A graphical presentation based on quantile charts was used to describe the optimization.

An empirical second-order polynomial model with three parameters was used with the equation:

$$
\text { Yield }=\beta_{0}+\beta_{1} x_{1}+\beta_{2} x_{2}+\beta_{3} x_{3}+\beta_{11} x_{1}^{2}+\beta_{22} x_{2}^{2}+\beta_{33} x_{3}^{2}+\beta_{12} x_{1} x_{2}+\beta_{13} x_{1} x_{3}+\beta_{23} x_{2} x_{3}
$$

where yield is NP yield (response variable); $\beta_{0}$ is interception coefficient; $\beta_{11}, \beta_{22}$, and $\beta_{33}$ are quadratic terms; $\beta_{12}, \beta_{13}$, and $\beta_{23}$ are interaction coefficients; and $x_{1}, x_{2}$, and $x_{3}$ are independent variables (fungal biomass (Extract), metal concentration (Conc), microwave power (Power), reaction time (Time)). The significance of the RSM model based on ANOVA is presented in Table S2 (Supplementary File). The final equation is as follows:

Yield $(\mathrm{mg})=-73+50$ Extract +40 Conc +0.09 Power +4.2 Time $-{ }^{*}$ Extract $16.50-,{ }^{*}$ Conc $-0.0002,{ }^{*}$ Power $0.2{ }^{*}$ Time (min) $-5.3,11.15$ Extract*, Conc -0.004 , Power $-0.6,+0.2$ Time

\section{3. $\mathrm{Ag} / \mathrm{CuO} \mathrm{NPs}$ Characterization}

The formation of $\mathrm{Ag} / \mathrm{CuO}$ NPs was monitored using a UV-Vis spectrophotometer (UH3500, Hitachi, Tokyo, Japan). Reducing and capping agents present in the fungal biomass were analyzed using a Fourier transform infrared spectrophotometer (FT-IR, Thermo Fisher Scientific, Waltham, MA, USA). The powder X-ray diffraction technique 
was used to analyze the structure and nature of the synthesized $\mathrm{Ag} / \mathrm{CuO}$ NPs using $\mathrm{CuK} \alpha$ radiation. The average size of the NPs was calculated using the Scherrer equation:

$$
\mathrm{D}=\mathrm{k} \lambda /(\beta \cos \theta)
$$

where $\mathrm{k}$ is the shape factor (0.9), $\beta$ the peak's full width at half-maximum (FWHM), D the average size, $\lambda$ the wavelength, and $\theta$ is the diffraction angle.

The morphology of the synthesized NPs was observed using a scanning electron microscope (SEM, ZEISS EVO, Waltham, MA, USA) coupled with energy dispersed X-ray spectroscopy (EDS) and a transmission electron microscope (TEM), Phillips CM200. The particle size histogram was calculated using ImageJ software and plotted using Origin Pro 8.5 software [31].

\subsection{Biological Activities of the $\mathrm{Ag} / \mathrm{CuO} \mathrm{NPs}$}

All biological tests were carried out as three replicates. The antioxidant activity analysis using the free radical 2,2-diphenyl-1-picrylhydrazyl (DPPH) was carried out as described by [32] with slight modifications. The NPs solution was mixed with $1 \mathrm{~mL}$ of freshly prepared DPPH $(1 \mathrm{mM})$ in methanol. The test solution was kept in the dark at room temperature for $30 \mathrm{~min}$, and the absorbance was recorded using UV-Vis spectroscopy at $517 \mathrm{~nm}$.

Hydrogen peroxide scavenging by the NPs was carried out as described by Fowsiya and Madhumitha [33]. Ascorbic acid was used as the standard. Scavenging was calculated using the following equation:

$$
\% \text { Scavenging }=\mathrm{Ac}-\mathrm{As} / \mathrm{Ac} \times 100
$$

where Ac and As indicate the absorbance of the control (phosphate buffer solution) and sample solution/standard solution. The lowered absorbance indicates the scavenging of free radicals by NPs.

The antibacterial activity of the NPs was analyzed using six bacterial species (Klebsiella pneumoniae, Enterobacter cloacae, Pseudomonas aeruginosa, Escherichia coli, Enterococcus faecalis, and Staphylococcus aureus) collected from the microbiology department of King Saud University and identified molecularly [34]. The inhibition of NPs was studied with the well-diffusion method [34]. The bacteria were first incubated at $37^{\circ} \mathrm{C}$ for $24 \mathrm{~h}$. NPs at $50 \mu \mathrm{g} / \mathrm{mL}$ concentration in dimethyl sulphoxide (DMSO) were added to wells in agar. The zone of inhibition (mean of width and length in $\mathrm{mm}$ ) around the wells was measured using a ruler after the incubation at $37^{\circ} \mathrm{C}$ for $24 \mathrm{~h}$. The minimum inhibitory concentration (MIC) and the lethal minimum bactericidal concentration (MBC) were determined using various concentrations $(1,5,10,15,20,25,35,45,50)$ of the NPs.

The cytotoxicity test was carried out as described previously [35]. The cells were kept in D-MEM medium enhanced with $10 \%$ fetal calf serum (FCS), $1 \mathrm{mM}$ sodium pyruvate, $2 \mathrm{mM}$ glutamine, $50 \mathrm{U} / \mathrm{mL}$ penicillin, $50 \mathrm{mg} / \mathrm{mL}$ streptomycin, and $100 \mathrm{mM}$ trivial amino acids. For morphological examinations, the cells were cultivated in 6-well plates at a centralization of $3 \times 105$ cells/well in $2 \mathrm{~mL}$ of complete medium. The cells were brooded in a humidified hatchery at $33{ }^{\circ} \mathrm{C}$ and $5 \% \mathrm{CO}_{2}$. The MTT test was utilized to quantify mitochondrial movement, as recently portrayed [34], with minor modifications. The cell culture medium was disposed of, and cells were hatched with $100 \mu \mathrm{L}$ of MTT for $2 \mathrm{~h}$ at $37^{\circ} \mathrm{C}, 5 \% \mathrm{CO}_{2}$. The MTT arrangement was then, at that point, disposed of, and $100 \mu \mathrm{L}$ of DMSO was added to each well. Optical density was perused on a microplate per user at $550 \mathrm{~nm}$, with a reference at $655 \mathrm{~nm}$ (EL800, Bio-Tek Instruments, Inc., Winooski, VT, USA). Cell death was determined as the proportion of the mean of OD obtained for each condition to that of the control (no molecule) condition:

$$
\% \text { Cell death }=\mathrm{OD}(\mathrm{s}) / \mathrm{OD}(\mathrm{c}) \times 100
$$

where OD (s) and OD (c) are the optical density of the sample and control. 


\section{Results}

\subsection{Optimization of Operating Variables}

Three-dimensional response surfaces and two-dimensional contour plots were presented to describe the optimization: the diagrams illustrate the effects of two factors on NP yield at a time. Figure 1 shows the effect of the fungal biomass (extract) and the concentration of total metals on NP yield after 15 min with $350 \mathrm{~W}$ microwave power. Increasing the metal concentration from $0.5 \mathrm{mM}$ to $1.5 \mathrm{mM}$ doubled the NP yield. Increasing the fungal extract from $1 \mathrm{mg}$ to $1.5 \mathrm{mg}$ reduced the yield. When the concentration was $1 \mathrm{mM}$, the maximal yield was achieved between 300 and $500 \mathrm{~W}$ and between 0.8 and $1.25 \mathrm{mg}$ extract (Figure 2).
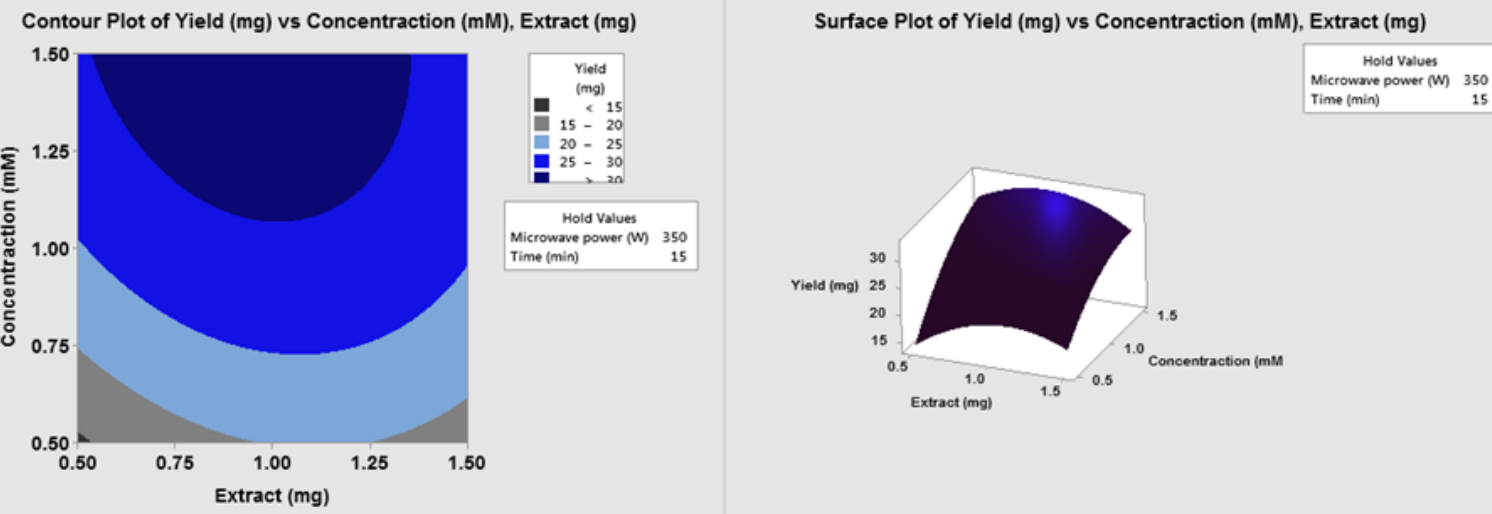

Figure 1. Fungal biomass (extract) and total metal concentration effect on NP yield.

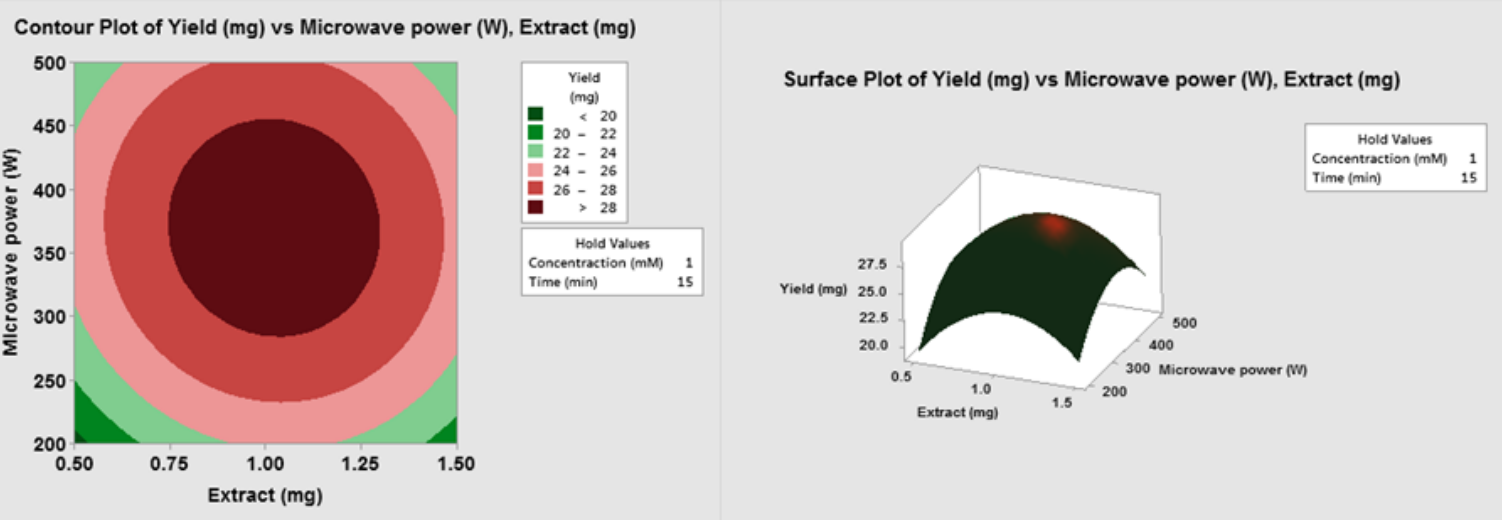

Figure 2. Fungal biomass (extract) and microwave power effect on NP yield.

A concentration of $1.5 \mathrm{mM}$ caused a decline in the NP yield (Figure 3). Considering the reaction time, the optimal time was $15 \mathrm{~min}$ (Figure 4). When the MW power and the concentration were kept constant, first an increase and then a decrease in the NP yield were observed along with both time and extract (Figure 4a). Increasing the concentration from $0.5 \mathrm{mM}$ to $1.5 \mathrm{mM}$ increased the NP yield gradually when the extract and MW power were constant (Figure 4b). The optimal MW power was $350 \mathrm{~W}$ and time $15 \mathrm{~min}$ (Figure 4c). In summary, the yield was, at lowest, $<15 \mathrm{mg}$ and, at highest, $32 \mathrm{mg}$. The final conditions were $1.5 \mathrm{mM}$ total metal concentration, $1.25 \mathrm{mg}$ fungal biomass, $350 \mathrm{~W}$, and $15 \mathrm{~min}$.

\subsection{UV-Vis Spectroscopy}

The UV-Vis spectra showed the maximum absorbance after $60 \mathrm{~min}$ (Figure 5). The formation of NPs started at $5 \mathrm{~min}$ and ended at $60 \mathrm{~min}$. 


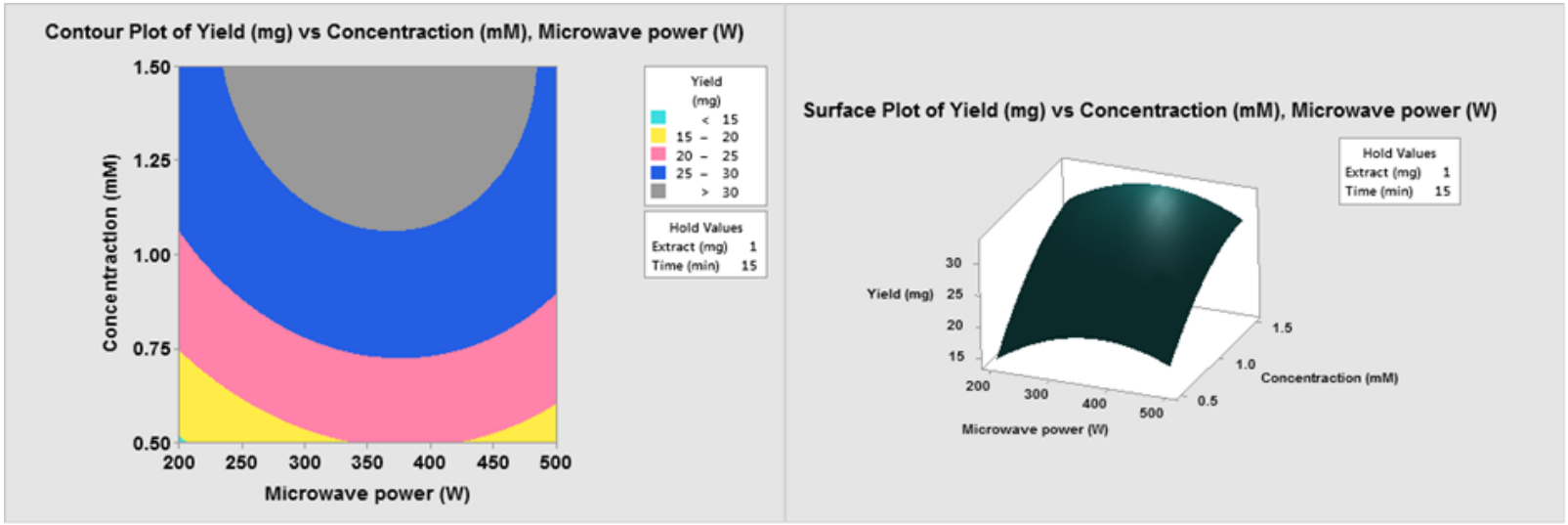

Figure 3. Microwave power and total metal concentration effect on NP yield.
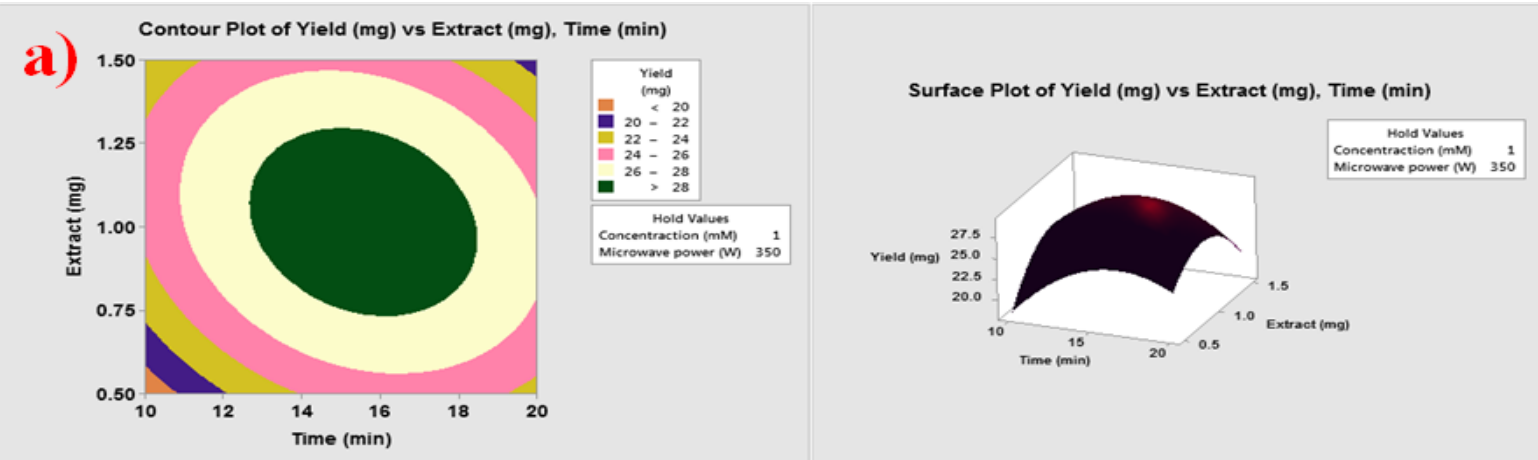

Contour Plot of Yield ( $\mathrm{mg}$ ) vs Concentraction (mM), Time (min)
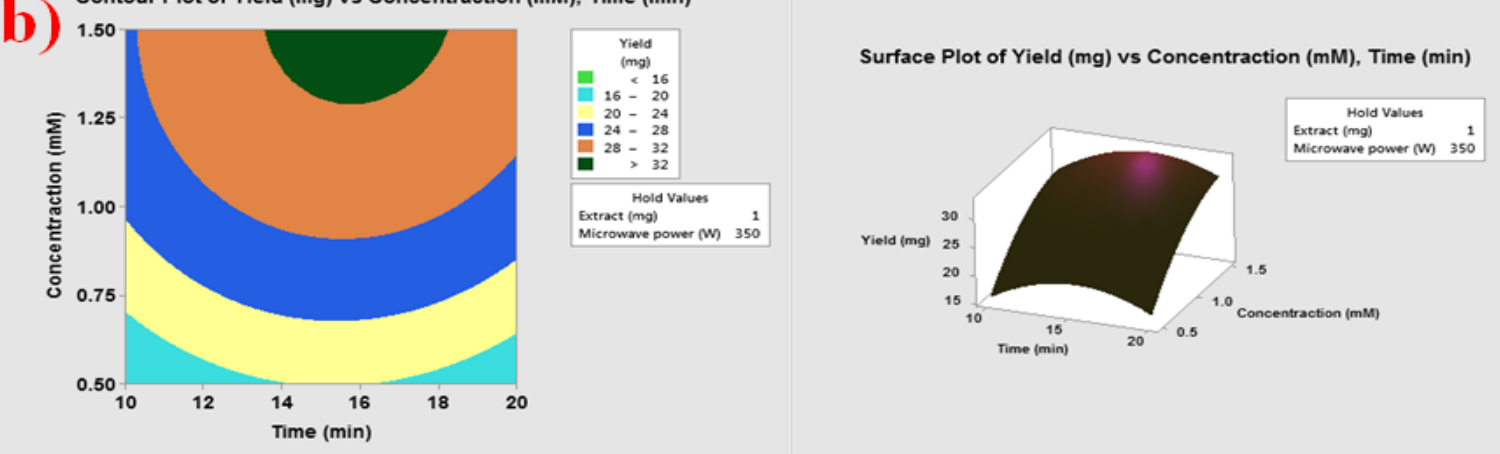

c)
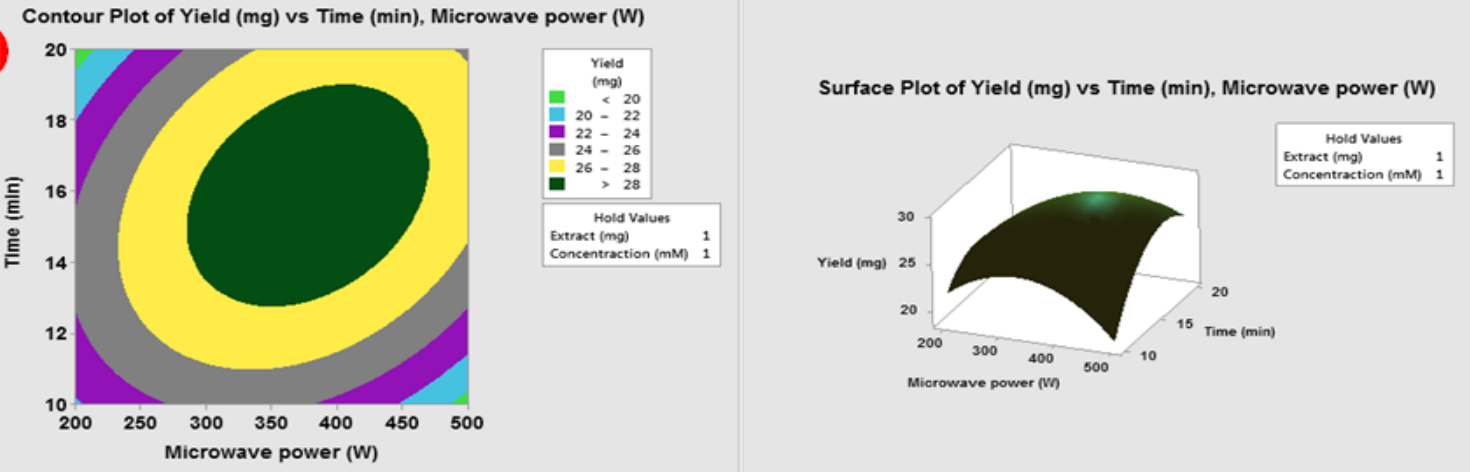

Figure 4. The effect of (a) time and fungal biomass (extract) (b) time and total metal concentration, and (c) time and microwave power on the yield of $\mathrm{Ag}-\mathrm{Cu}$ NPs. 


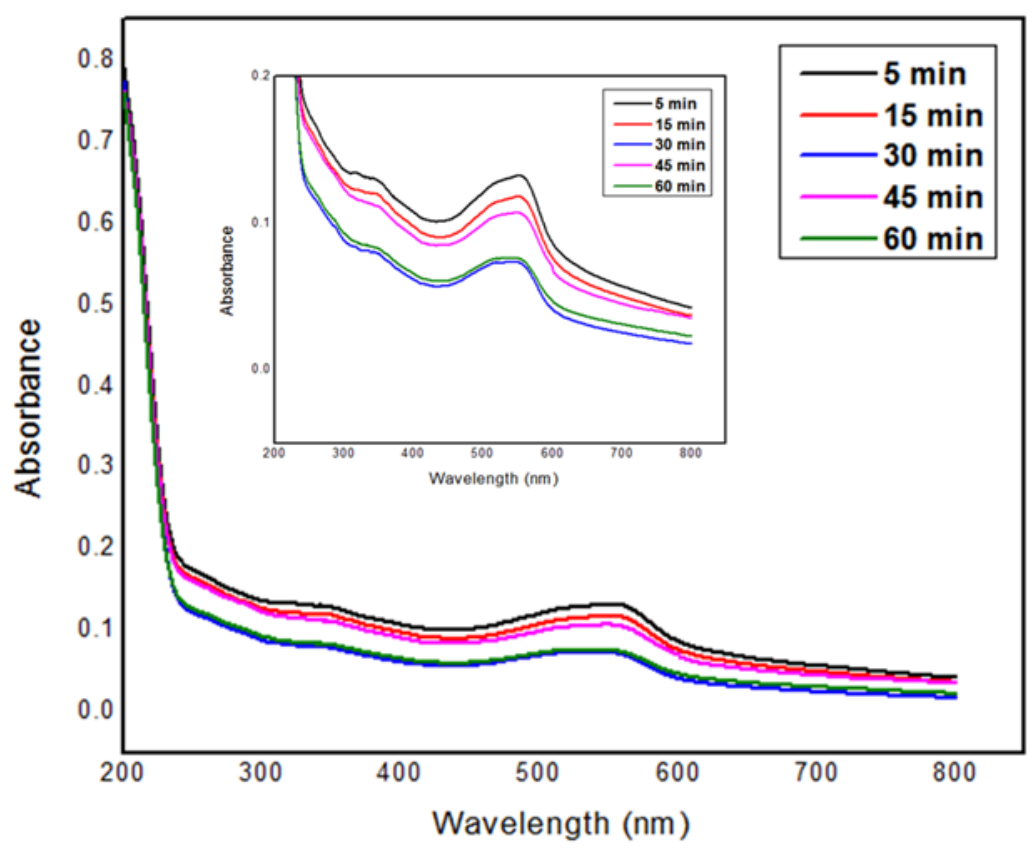

Figure 5. UV-Vis spectra of $\mathrm{Ag} / \mathrm{CuO}$ NPs formation.

\subsection{FT-IR Analysis}

The FT-IR spectrum showed vibrational stretching at $3432 \mathrm{~cm}^{-1}$ relating to $-\mathrm{OH}$ extending, $1638 \mathrm{~cm}^{-1}$ relating to $\mathrm{C}-\mathrm{C}$ bond, and 663 relating to $\mathrm{Cu}$ ions (Figure 6.). The broad peak corresponding to -OH has been reduced in the NPs peak. Therefore, the $-\mathrm{OH}$ group acts as a good reducing, stabilizing, and capping agent of the NPs. The FT-IR spectrum was consistent with the UV-Vis spectrum.

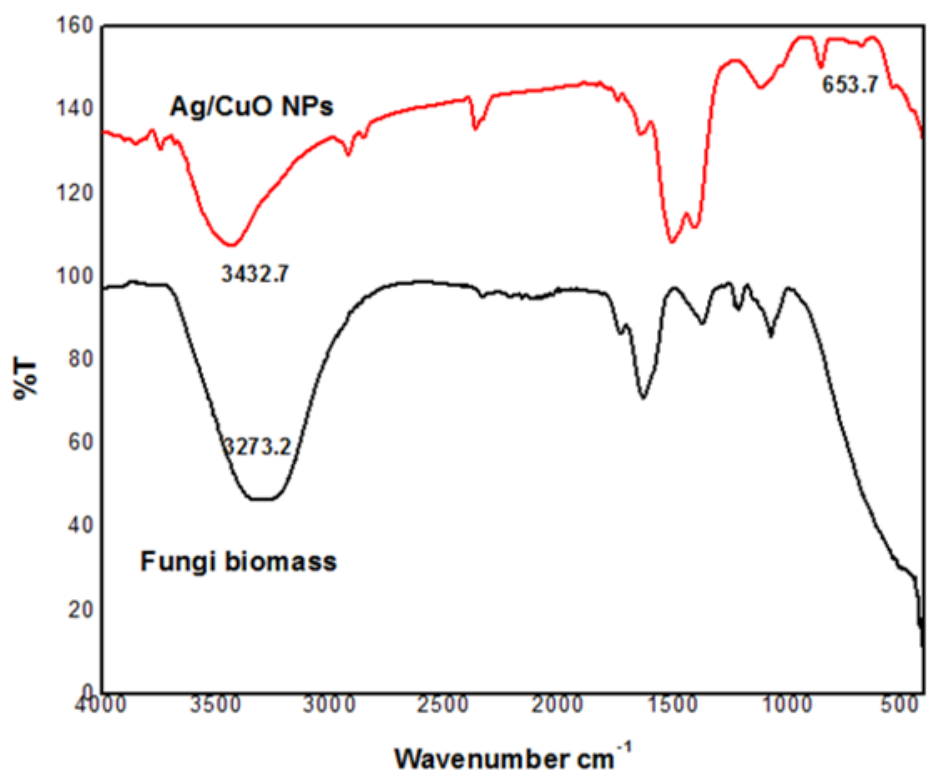

Figure 6. FT-IR spectra of synthesized Ag/Cu NPs.

\subsection{XRD Analysis}

The X-beam diffraction pattern (Figure 7) shows sharp crystalline peaks of Ag/ CuO NPs. Six diffraction peaks at $37.2^{\circ}, 45.45^{\circ}, 48.3^{\circ}, 65.21^{\circ}, 75.1^{\circ}$, and $81.3^{\circ}$ compare to the standard face-centered cubic designs. The intense peak at $48.36^{\circ}$ affirmed the presence of $\mathrm{AgO}$, and the peaks at $32.41^{\circ}$ and $37.2^{\circ}$ affirmed $\mathrm{CuO}$. 


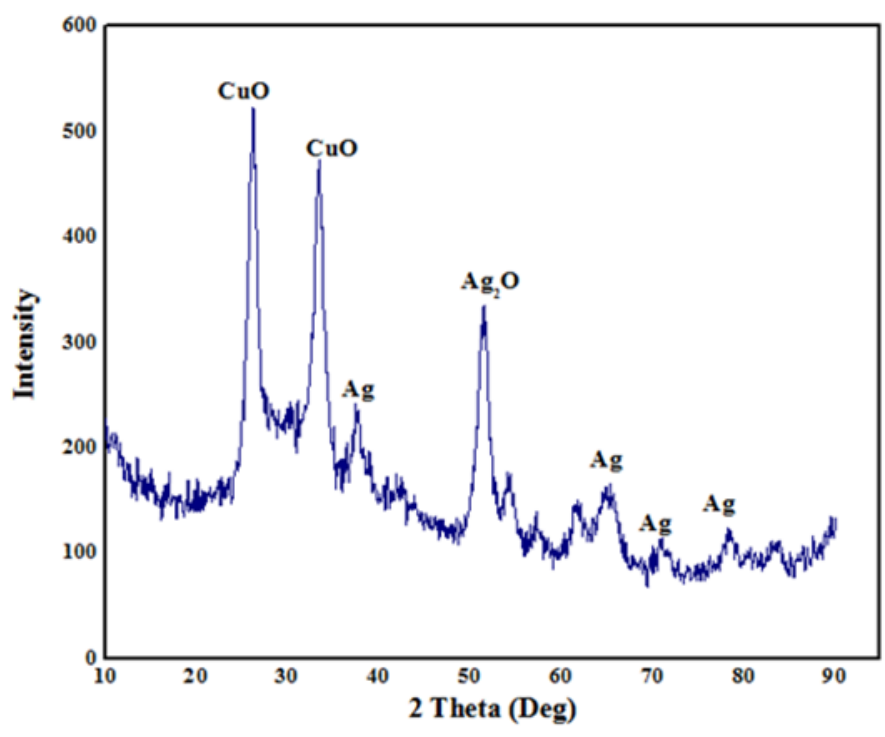

Figure 7. XRD pattern of fungal biomass-mediated Ag/Cu NPs.

\subsection{Morphological Analysis}

SEM images showed the agglomerated and spherical shapes of the bi-metallic NPs (Figure 8a). From the TEM image, spherical NPs and the dispersion of agglomerated particles were observed (Figure 8b). The elemental analysis showed the presence of $\mathrm{Ag}, \mathrm{Cu}$, and $\mathrm{O}$ without any impurities (Figure 8c). The Scherrer equation gave the average NP size of $22 \mathrm{~nm}$. The particle size histogram shows that the particle size 20-22 mm was the most common, having 11 counts (Figure $8 d)$. Small $(12-18 \mathrm{~nm})$ and large $(>30 \mathrm{~nm})$ were in the minority with fewer than 10 counts combined.

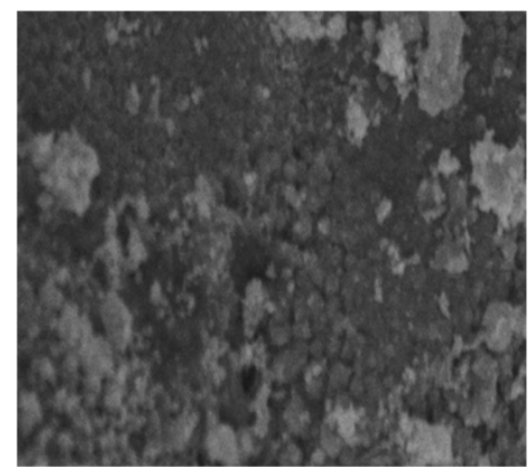

(a)

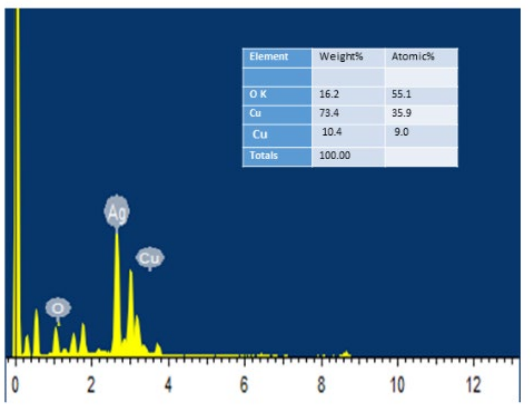

(c)

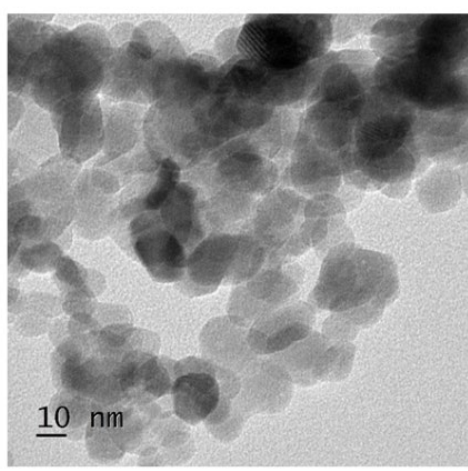

(b)

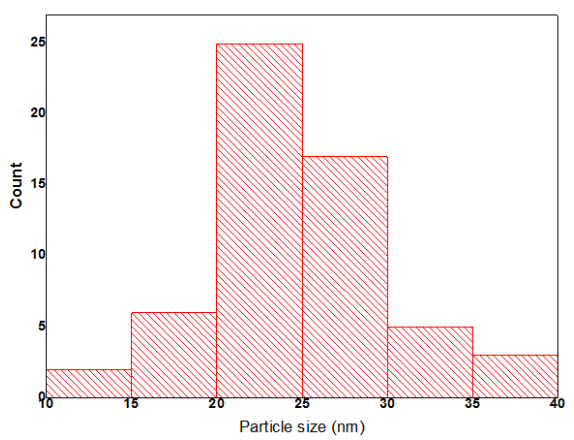

(d)

Figure 8. Images of SEM (a), TEM (b), and EDS (c) and the particle size histogram (d) of Ag/Cu NPs. 


\subsection{Antioxidant Activity}

The DPPH scavenging activity increased with the NP concentration (Figure 9a). Hydrogen peroxide scavenging inhibition increased from $30 \%$ in $100 \mathrm{mg} / \mathrm{L} \mathrm{NP}$ to $75 \%$ in $500 \mathrm{mg} / \mathrm{L}$ NP (Figure 9b).

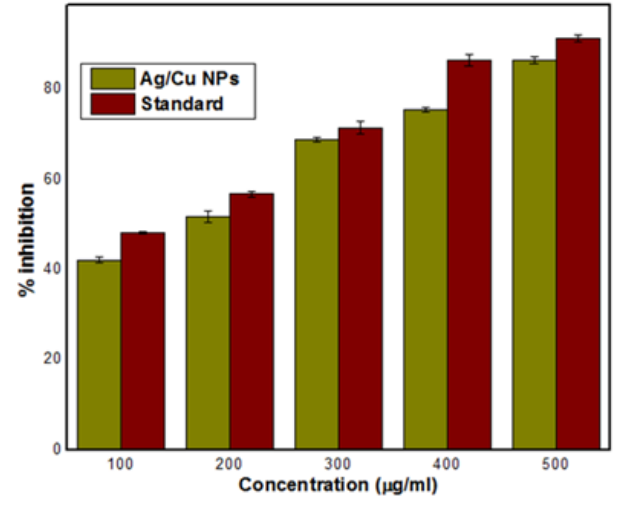

(a)

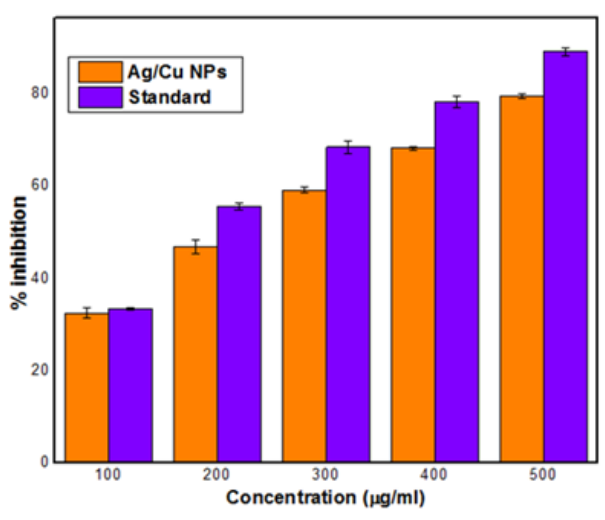

(b)

Figure 9. DPPH (a) and hydrogen peroxide (b) scavenging activity of Ag-Cu NPs (mean and SD, $n=3$ ).

\subsection{Antibacterial Activity}

The highest inhibition of the NPs was observed against K. pneumonia, E. cloacae, and P. aeruginosa. Their inhibition zones varied between $9 \mathrm{~mm}$ and $22 \mathrm{~mm}$ and were almost double those of E. coli, E. faecalis, and S. aureus, which varied between $3 \mathrm{~mm}$ and $12 \mathrm{~mm}$ (Table 1). The inhibition was about double for each bacterium at the highest NP concentration $(5 \mu \mathrm{g} / \mathrm{mL})$ to the lowest concentration $(0.5 \mathrm{mg} / \mathrm{mL})$. The MIC varied between $0.2 \mu \mathrm{g} / \mathrm{mL}$ against E. cloacae and K. pneumoniae and $1 \mu \mathrm{g} / \mathrm{mL}$ against $E$. faecalis (Table 2). For S. aureus, the MIC was $1 \mu \mathrm{g} / \mathrm{mL}$ and for P. aeruginosa $0.3 \mu \mathrm{g} / \mathrm{mL}$. The MBC was lowest $(0.5 \mu \mathrm{g} / \mathrm{mL})$ to $P$. aeruginosa and highest $(1.5 \mu \mathrm{g} / \mathrm{mL})$ to S. aureus (Table 2$)$.

Table 1. Antibacterial activity (as the zone of inhibition, mean $\pm \mathrm{SD}, n=3$ ) of Ag-Cu NPs against six bacterial species.

\begin{tabular}{lllllll}
\hline \multirow{2}{*}{ NPs Concentration $(\boldsymbol{\mu g} / \mathbf{m L})$} & \multicolumn{4}{l}{ Zone of Inhibition $(\mathbf{m m})$ Against Bacteria } \\
\cline { 2 - 7 } & K. pneumoniae & E. cloacae & P. aeruginosa & E. coli & E. faecalis & S. aureus \\
\hline 0.5 & $10 \pm 1.6$ & $11 \pm 1.5$ & $9 \pm 1.6$ & $6.5 \pm 2.4$ & $3 \pm 1.5$ & $6 \pm 1.4$ \\
1 & $12 \pm 1.5$ & $13 \pm 1.2$ & $11 \pm 1.8$ & $7.6 \pm 2.1$ & $4 \pm 1.6$ & $7 \pm 1.5$ \\
2.5 & $15 \pm 1.7$ & $15 \pm 1.6$ & $14 \pm 2.1$ & $9 \pm 2.2$ & $6 \pm 1.6$ & $9 \pm 1.4$ \\
4 & $19 \pm 2.1$ & $18 \pm 2.2$ & $16 \pm 2.5$ & $10 \pm 1.2$ & $9 \pm 2.3$ & $10 \pm 2.6$ \\
5 & $21 \pm 2.2$ & $22 \pm 2.5$ & $20 \pm 2.5$ & $12 \pm 2.4$ & $10 \pm 2.6$ & $15 \pm 2.0$ \\
\hline
\end{tabular}

Table 2. Minimum inhibitory concentration (MIC) and minimum bactericidal concentration (MBC) of Ag-Cu NPs against different bacterial species.

\begin{tabular}{lll}
\hline \multirow{2}{*}{ Bacteria } & NPs Concentration $(\mu \mathrm{g} / \mathrm{mL})$ & \\
\cline { 2 - 3 } & MIC & MBC \\
\hline K. pneumoniae & 0.2 & 1 \\
E. cloacae & 0.2 & 1 \\
P. aeruginosa & 0.3 & 0.5 \\
E. coli & 0.5 & 0.6 \\
E. faecalis & 1 & 0.8 \\
S. aureus & 0.8 & 1.5 \\
\hline
\end{tabular}




\subsection{Cytotoxicity Test}

Bi-metallic NPs caused the highest cell death at a $5 \mu \mathrm{g} / \mathrm{mL}$ NP concentration, where $95 \%$ of the cells died in $48 \mathrm{~h}$ (Figure 10$)$. At the highest NP concentration $(50 \mu \mathrm{g} / \mathrm{mL})$, cell death was lower, at $90 \%$.

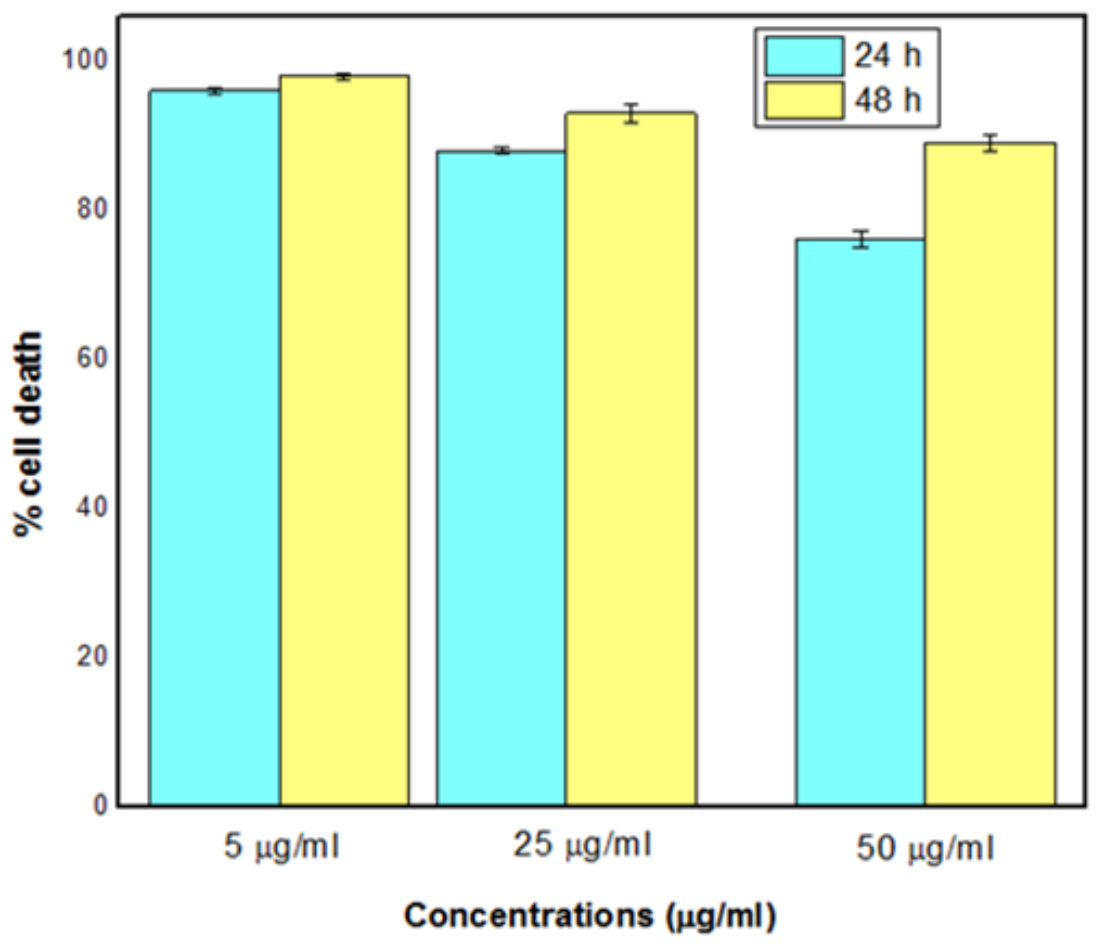

Figure 10. Cytotoxicity at different concentrations of Ag-Cu NPs (mean and SD, n = 3) after 24 and $48 \mathrm{~h}$.

\section{Discussion}

The novelty of this work was to use microwaves and fungal biomass to synthesize bi-metallic Ag-Cu NPs and optimize the process conditions using statistical methods. The synthesis process depended on the amount of fungal biomass used, the concentration of metals, irradiation power, and the reaction time, which we optimized for the final synthesis.

The synthesized bi-metallic NPs showed antimicrobial activities against three clinically relevant Gram-negative bacterial pathogens, namely K. pneumoniae, E. cloacae, and P. aeruginosa. Three of the bacteria, Gram-negative E. coli and Gram-positive E. faecalis and $S$. aureus were inhibited slightly. The higher inhibition of Gram-positive bacteria has been proposed, and for instance, E. coli and P. aeruginosa were inhibited less than S. aureus by $\mathrm{Zn}$ and $\mathrm{Cu}$ NPs [36,37]. Our study does not support the separation between Gram-positive and Gram-negative bacteria. It may be that the NP characteristics may be of great importance, in addition to the resistance of the particular bacterial strain [38]. Ag NPs have been shown to efficiently inhibit P. aeruginosa, E. coli, and S. aureus. E. coli was inhibited, for instance, by Zn NPs [39] and Ag NPs [40]. Moreover, methicillin-resistant S. aureus (MRSA) has recently been shown to be inhibited by NPs [41-43]. For some reason, our bi-metallic NPs did not inhibit $S$. aureus especially efficiently. More than double the minimum inhibitory concentration and thrice the minimum bactericidal concentration were needed to inhibit S. aureus compared to P. aeruginosa. All bacterial species that we tested have been inhibited by some metal NPs previously, at least to some extent [44-48].

Bi-metallic NPs are promising antimicrobial agents, especially against multidrugtolerant pathogenic microorganisms [49]. The bacteria S. pneumonia, P. aeruginosa, E. coli, Bacillus subtilis, and S. aureus were inhibited efficiently by Ag-Cu NPs previously [50-52]. The ultra-high antibacterial activity of $2 \mathrm{~nm}$ size Ag-Cu NPs [53] was observed against 
E. coli and S. aureus. Ag-Cu NPs have been proposed to be useful to inhibit bacteria in food packages [54-56].

In general, NPs with a size of 1-100 nm have shown strong antimicrobial effects against both Gram-positive and Gram-negative bacteria [57]. Smaller particles are more efficient because the ratio of the surface region to the volume increases when the particle size diminishes. Our NPs were relatively small, varying between 12 and $30 \mathrm{~nm}$. Although only the dynamic light scattering ((DLS) method would give a precise size of the NPs, we suggest that the process we propose here is suitable for producing small and efficient bi-metallic NPs.

Microwave power and optimization of the synthesizing conditions using RSM have been carried out only recently. By optimizing the process, very small Se and $\mathrm{Cu}$ nanoparticles (1-10 nm) were synthesized using a microwave power of $790 \mathrm{~W}$ for $15 \mathrm{~min}$ [58,59]. In our tests, the highest power, $500 \mathrm{~W}$, was not the most efficient in producing bi-metallic Ag-Cu NPs. Instead, the highest yield was reached in 15 min with $350 \mathrm{~W}$. Elsewhere, a constant $800 \mathrm{~W}$ power, and the maximum tested time $(6 \mathrm{~min})$ produced Ag NPs of $46 \mathrm{~nm}$ size [60]. Relatively small Fe NPs (14 nm) were produced in $10 \mathrm{~min}$ [61]. We were able to synthesize smaller than $30 \mathrm{~nm}$ bi-metallic NPs. It is possible that testing a larger scale of parameter values would produce smaller NPs, which is a future challenge.

\section{Conclusions}

The synthesis of Ag-Cu NPs was optimized using statistical methods. The optimal conditions of four process parameters (fungal biomass, microwave power, metal concentration, and reaction time) doubled the yield of nanoparticles when compared to starting conditions. The optimal synthesis produced bi-metallic nanoparticles with a size of $20-30 \mathrm{~nm}$. The nanoparticles had antibacterial, antioxidant, and cytotoxic properties. Three of the six tested bacterial pathogens were remarkably inhibited in our tests, while the cytotoxicity and antioxidant activities were high in general. Smaller particles with higher activities might be synthesized using a wider scale of process parameter values and by further optimizing the process. It seems evident that the optimization procedure should be included in each future nanoparticle synthesis study.

Supplementary Materials: The following are available online at https:/ / www.mdpi.com/article/10.3 390/app12031384/s1. Table S1: Parameters and their levels used to optimize the production of Ag/CuO NPs with RSM model and the yield of Ag/CuO NPs in different treatments, Table S2: ANOVA table of the final RSM model.

Funding: This research was funded by Researchers Supporting Project number (RSP-2021/364), King Saud University, Riyadh, Saudi Arabia.

Institutional Review Board Statement: Not applicable.

Informed Consent Statement: Not applicable.

Data Availability Statement: All data related to this manuscript is incorporated in the manuscript only.

Conflicts of Interest: The author declare no competing financial or commercial interests.

\section{References}

1. Saratale, R.G.; Karuppusamy, I.; Saratale, G.D.; Pugazhendhi, A.; Kumar, G.; Park, Y.; Ghodake, G.S.; Bharagava, R.N.; Banu, R.; Shin, H.S. A comprehensive review on green nanomaterials using biological systems: Recent perception and their future applications. Colloids Surf. B Biointerfaces 2018, 170, 20-35. [CrossRef]

2. Dutta, D.; Das, B.M. Scope of green nanotechnology towards amalgamation of green chemistry for cleaner environment: A review on synthesis and applications of green nanoparticles. Environ. Nanotechnol. Monit. Manag. 2021, 15, 100418. [CrossRef]

3. Pareek, V.; Bhargava, A.; Gupta, R.; Jain, N.; Panwar, J. Synthesis and Applications of Noble Metal Nanoparticles: A Review. Adv. Sci. Eng. Med. 2017, 9, 527-544. [CrossRef]

4. Saravanan, A.; Kumar, P.S.; Karishma, S.; Vo, D.-V.N.; Jeevanantham, S.; Yaashikaa, P.; George, C.S. A review on biosynthesis of metal nanoparticles and its environmental applications. Chemosphere 2021, 264, 128580. [CrossRef] [PubMed] 
5. Beyene, H.D.; Werkneh, A.A.; Bezabh, H.K.; Ambaye, T.G. Synthesis paradigm and applications of silver nanoparticles (AgNPs), a review. Sustain. Mater. Technol. 2017, 13, 18-23. [CrossRef]

6. Vahabi, K.; Mansoori, G.; Karimi, S. Biosynthesis of Silver Nanoparticles by Fungus Trichoderma Reesei (A Route for Large-Scale Production of AgNPs). Insciences J. 2011, 1, 65-79. [CrossRef]

7. Ameen, F.; Al-Homaidan, A.A.; Al-Sabri, A.; Almansob, A.; AlNAdhari, S. Anti-oxidant, anti-fungal and cytotoxic effects of silver nanoparticles synthesized using marine fungus Cladosporium halotolerans. Appl. Nanosci. 2021, 1-9. [CrossRef]

8. Khan, A.U.; Malik, N.; Khan, M.; Cho, M.H.; Khan, M.M. Fungi-assisted silver nanoparticle synthesis and their applications. Bioprocess Biosyst. Eng. 2018, 41, 1-20. [CrossRef]

9. Patel, M.; Surti, M.; Siddiqui, A.J.; Adnan, M. Fungi and metal nanoparticles. In Handbook of Greener Synthesis of Nanomaterials and Compounds; Elsevier: Amsterdam, The Netherlands, 2021; pp. 861-890.

10. Ahluwalia, V.; Kumar, J.; Sisodia, R.; Shakil, N.A.; Walia, S. Green synthesis of silver nanoparticles by Trichoderma harzianum and their bio-efficacy evaluation against Staphylococcus aureus and Klebsiella pneumonia. Ind. Crop. Prod. 2014, 55, 202-206. [CrossRef]

11. Azmath, P.; Baker, S.; Rakshith, D.; Satish, S. Mycosynthesis of silver nanoparticles bearing antibacterial activity. Saudi Pharm. J. 2016, 24, 140-146. [CrossRef]

12. Guilger-Casagrande, M.; Lima, R. Synthesis of Silver Nanoparticles Mediated by Fungi: A Review. Front. Bioeng. Biotechnol. 2019, 7, 287. [CrossRef] [PubMed]

13. Ameen, F.; Dawoud, T.; AlNadhari, S. Ecofriendly and low-cost synthesis of ZnO nanoparticles from Acremonium potronii for the photocatalytic degradation of azo dyes. Environ. Res. 2021, 202, 111700. [CrossRef] [PubMed]

14. Padilla-Cruz, A.L.; Garza-Cervantes, J.A.; Vasto-Anzaldo, X.G.; García-Rivas, G.; León-Buitimea, A.; Morones-Ramírez, J.R. Synthesis and design of Ag-Fe bimetallic nanoparticles as antimicrobial synergistic combination therapies against clinically relevant pathogens. Sci. Rep. 2021, 11, 5351. [CrossRef] [PubMed]

15. Duan, M.; Jiang, L.; Zeng, G.; Wang, D.; Tang, W.; Liang, J.; Wang, H.; He, D.; Liu, Z.; Tang, L. Bimetallic nanoparticles/metalorganic frameworks: Synthesis, applications and challenges. Appl. Mater. Today 2020, 19, 100564. [CrossRef]

16. Basavegowda, N.; Mandal, T.K.; Baek, K.-H. Bimetallic and Trimetallic Nanoparticles for Active Food Packaging Applications: A Review. Food Bioprocess Technol. 2019, 13, 30-44. [CrossRef]

17. Sharma, G.; Kumar, A.; Sharma, S.; Naushad, M.; Dwivedi, R.P.; Alothman, Z.; Mola, G.T. Novel development of nanoparticles to bimetallic nanoparticles and their composites: A review. J. King Saud Univ.-Sci. 2019, 31, 257-269. [CrossRef]

18. Zhang, H.; Haba, M.; Okumura, M.; Akita, T.; Hashimoto, S.; Toshima, N. Novel Formation of Ag/Au Bimetallic Nanoparticles by Physical Mixture of Monometallic Nanoparticles in Dispersions and Their Application to Catalysts for Aerobic Glucose Oxidation. Langmuir 2013, 29, 10330-10339. [CrossRef]

19. Tsai, C.-H.; Chen, S.-Y.; Song, J.-M.; Chen, I.-G.; Lee, H.-Y. Thermal stability of Cu@Ag core-shell nanoparticles. Corros. Sci. 2013, 74, 123-129. [CrossRef]

20. Tan, K.S.; Cheong, K.Y. Advances of $\mathrm{Ag}, \mathrm{Cu}$, and $\mathrm{Ag}-\mathrm{Cu}$ alloy nanoparticles synthesized via chemical reduction route. J. Nanoparticle Res. 2013, 15, 1537. [CrossRef]

21. Shin, K.; Kim, D.H.; Yeo, S.C.; Lee, H.M. Structural stability of AgCu bimetallic nanoparticles and their application as a catalyst: A DFT study. Catal. Today 2012, 185, 94-98. [CrossRef]

22. Cai, Y.; Piao, X.; Gao, W.; Zhang, Z.; Nie, E.; Sun, Z. Large-scale and facile synthesis of silver nanoparticles via a microwave method for a conductive pen. RSC Adv. 2017, 7, 34041-34048. [CrossRef]

23. Ashraf, H.; Anjum, T.; Riaz, S.; Naseem, S. Microwave-Assisted Green Synthesis and Characterization of Silver Nanoparticles Using Melia azedarach for the Management of Fusarium Wilt in Tomato. Front. Microbiol. 2020, 11, 238. [CrossRef] [PubMed]

24. Tamilvanan, A.; Balamurugan, K.; Mohanraj, T.; Selvakumar, P.; Madhankumar, B. Parameter optimization of copper nanoparticle synthesis by electrodeposition process using RSM and CS. Mater. Today Proc. 2021, 45, 751-756. [CrossRef]

25. Tangsiri, R.; Nezamzadeh-Ejhieh, A. Cadmium sulfide nanoparticles: Synthesis, brief characterization and experimental design by response surface methodology (RSM) in the photodegradation of ranitidine hydrochloride. Chem. Phys. Lett. 2020, 758, 137919. [CrossRef]

26. Ameen, F.; Hadi, S.; Moslem, M.; Al-Sabri, A.; Yassin, M.A. Biodegradation of engine oil by fungi from mangrove habitat. J. Gen. Appl. Microbiol. 2015, 61, 185-192. [CrossRef]

27. Ameen, F.; Dawoud, T.M.; Alshehrei, F.; Alsamhary, K.; Almansob, A. Decolorization of acid blue 29, disperse red 1 and congo red by different indigenous fungal strains. Chemosphere 2021, 271, 129532. [CrossRef]

28. Cuevas, R.; Durán, N.; Diez, M.C.; Tortella, G.; Rubilar, O. Extracellular Biosynthesis of Copper and Copper Oxide Nanoparticles by Stereum hirsutum, a Native White-Rot Fungus from Chilean Forests. J. Nanomater. 2015, 2015, 57. [CrossRef]

29. Ghosal, P.S.; Gupta, A.K.; Sulaiman, A. Multivariate optimization of process parameters in the synthesis of calcined Ca-Al (NO3) LDH for defluoridation using 33 factorial, central composite and Box-Behnken design. J. Environ. Sci. Health Part A 2016, 51, 86-96. [CrossRef]

30. Torabfam, M.; Jafarizadeh-Malmiri, H. Microwave-enhanced silver nanoparticle synthesis using chitosan biopolymer: Optimization of the process conditions and evaluation of their characteristics. Green Process. Synth. 2017, 7, 530-537. [CrossRef]

31. Consolo, V.F.; Torres-Nicolini, A.; Alvarez, V.A. Mycosinthetized Ag, CuO and ZnO nanoparticles from a promising Trichoderma harzianum strain and their antifungal potential against important phytopathogens. Sci. Rep. 2020, 10, 20499. [CrossRef] 
32. Ameen, F.; Stephenson, S.L.; AlNadhari, S.; Yassin, M.A. Isolation, identification and bioactivity analysis of an endophytic fungus isolated from Aloe vera collected from Asir desert, Saudi Arabia. Bioprocess Biosyst. Eng. 2021, 44, 1063-1070. [CrossRef] [PubMed]

33. Fowsiya, J.; Madhumitha, G. Preliminary phytochemical analysis, Antioxidant and cytotoxicity test of Carissa edulis Vahl dried fruits. In IOP Conference Series: Materials Science and Engineering; IOP Publishing: Bristol, UK, 2017; Volume 263, p. 22018.

34. Sonbol, H.; Ameen, F.; AlYahya, S.; Almansob, A.; Alwakeel, S. Padina boryana mediated green synthesis of crystalline palladium nanoparticles as potential nanodrug against multidrug resistant bacteria and cancer cells. Sci. Rep. 2021, 11, 5444. [CrossRef] [PubMed]

35. Al-Enazi, N.M.; Ameen, F.; Alsamhary, K.; Dawoud, T.; Al-Khattaf, F.; AlNadhari, S. Tin oxide nanoparticles $\left(\mathrm{SnO}_{2}-\mathrm{NPs}\right)$ synthesis using Galaxaura elongata and its anti-microbial and cytotoxicity study: A greenery approach. Appl. Nanosci. 2021, 1-9. [CrossRef]

36. Azam, A.; Ahmed, A.S.; Oves, M.; Khan, M.S.; Habib, S.S.; Memic, A. Antimicrobial activity of metal oxide nanoparticles against Gram-positive and Gram-negative bacteria: A comparative study. Int. J. Nanomed. 2012, 7, 6003-6009. [CrossRef] [PubMed]

37. Premanathan, M.; Karthikeyan, K.; Jeyasubramanian, K.; Manivannan, G. Selective toxicity of ZnO nanoparticles toward Grampositive bacteria and cancer cells by apoptosis through lipid peroxidation. Nanomed. Nanotechnol. Biol. Med. 2011, 7, 184-192. [CrossRef]

38. Pareek, V.; Gupta, R.; Panwar, J. Do physico-chemical properties of silver nanoparticles decide their interaction with biological media and bactericidal action? A review. Mater. Sci. Eng. C 2018, 90, 739-749. [CrossRef]

39. Happy, A.; Soumya, M.; Kumar, S.V.; Rajeshkumar, S.; Sheba, R.D.; Lakshmi, T.; Nallaswamy, V.D. Phyto-assisted synthesis of zinc oxide nanoparticles using Cassia alata and its antibacterial activity against Escherichia coli. Biochem. Biophys. Rep. 2019, 17, 208-211. [CrossRef]

40. Xiao, X.; He, E.-J.; Lu, X.-R.; Wu, L.-J.; Fan, Y.-Y.; Yu, H.-Q. Evaluation of antibacterial activities of silver nanoparticles on culturability and cell viability of Escherichia coli. Sci. Total Environ. 2021, 794, 148765. [CrossRef]

41. Vanamala, K.; Tatiparti, K.; Bhise, K.; Sau, S.; Scheetz, M.H.; Rybak, M.J.; Andes, D.; Iyer, A.K. Novel approaches for the treatment of methicillin-resistant Staphylococcus aureus: Using nanoparticles to overcome multidrug resistance. Drug Discov. Today 2021, 26, 31-43. [CrossRef]

42. Kadiyala, U.; Turali-Emre, E.S.; Bahng, J.H.; Kotov, N.A.; VanEpps, J.S. Unexpected insights into antibacterial activity of zinc oxide nanoparticles against methicillin resistant Staphylococcus aureus (MRSA). Nanoscale 2018, 10, 4927-4939. [CrossRef]

43. Tamboli, D.P.; Lee, D.S. Mechanistic antimicrobial approach of extracellularly synthesized silver nanoparticles against gram positive and gram negative bacteria. J. Hazard. Mater. 2013, 260, 878-884. [CrossRef]

44. Bouafia, A.; Laouini, S.E. Plant-mediated synthesis of iron oxide nanoparticles and evaluation of the antimicrobial activity: A review. Mini. Rev. Org. Chem. 2021, 18, 725-734. [CrossRef]

45. Shanmuganathan, R.; Karuppusamy, I.; Saravanan, M.; Muthukumar, H.; Ponnuchamy, K.; Ramkumar, V.S.; Pugazhendhi, A Synthesis of Silver Nanoparticles and their Biomedical Applications-A Comprehensive Review. Curr. Pharm. Des. 2019, 25, 2650-2660. [CrossRef]

46. Rana, A.; Yadav, K.; Jagadevan, S. A comprehensive review on green synthesis of nature-inspired metal nanoparticles: Mechanism, application and toxicity. J. Clean. Prod. 2020, 272, 122880. [CrossRef]

47. Singh, A.C.; Asif, M.; Bacher, G.; Danielsson, B.; Willander, M.; Bhand, S. Nanoimmunosensor based on ZnO nanorods for ultrasensitive detection of $17 \beta$-Estradiol. Biosens. Bioelectron. 2019, 126, 15-22. [CrossRef]

48. Li, J.; Tang, M.; Xue, Y. Review of the effects of silver nanoparticle exposure on gut bacteria. J. Appl. Toxicol. 2019, 39, 27-37. [CrossRef]

49. Ali, S.; Sharma, A.S.; Ahmad, W.; Zareef, M.; Hassan, M.; Viswadevarayalu, A.; Jiao, T.; Li, H.; Chen, Q. Noble Metals Based Bimetallic and Trimetallic Nanoparticles: Controlled Synthesis, Antimicrobial and Anticancer Applications. Crit. Rev. Anal. Chem. 2020, 51, 454-481. [CrossRef]

50. Medina, J.; Garcia-Perez, V.I.; Zanella, R. Metallic composites based on Ag, Cu, Au and Ag-Cu nanoparticles with distinctive bactericidal effect on varied species. Mater. Today Commun. 2021, 26, 102182. [CrossRef]

51. Al-Haddad, J.; Alzaabi, F.; Pal, P.; Rambabu, K.; Banat, F. Green synthesis of bimetallic copper-silver nanoparticles and their application in catalytic and antibacterial activities. Clean Technol. Environ. Policy 2019, 22, 269-277. [CrossRef]

52. Reyes-Blas, M.; Maldonado-Luna, N.M.; Rivera-Quiñones, C.M.; Vega-Avila, A.L.; Roman-Velázquez, F.R.; Perales-Perez, O.J. Single Step Microwave Assisted Synthesis and Antimicrobial Activity of Silver, Copper and Silver-Copper Nanoparticles. J. Mater. Sci. Chem. Eng. 2020, 8, 13. [CrossRef]

53. Yang, L.; Chen, L.; Chen, Y.-C.; Kang, L.; Yu, J.; Wang, Y.; Lu, C.; Mashimo, T.; Yoshiasa, A.; Lin, C.-H. Homogeneously alloyed nanoparticles of immiscible Ag-Cu with ultrahigh antibacterial activity. Colloids Surf. B Biointerfaces 2019, 180, 466-472. [CrossRef] [PubMed]

54. Ahmed, J.; Arfat, Y.A.; Bher, A.; Mulla, M.; Jacob, H.; Auras, R. Active Chicken Meat Packaging Based on Polylactide Films and Bimetallic Ag-Cu Nanoparticles and Essential Oil. J. Food Sci. 2018, 83, 1299-1310. [CrossRef] [PubMed]

55. Ahmed, J.; Mulla, M.; Arfat, Y.A.; Bher, A.; Jacob, H.; Auras, R. Compression molded LLDPE films loaded with bimetallic (Ag-Cu) nanoparticles and cinnamon essential oil for chicken meat packaging applications. LWT 2018, 93, 329-338. [CrossRef] 
56. Mamatha, G.; Sowmya, P.; Madhuri, D.; Babu, N.M.; Kumar, D.S.; Charan, G.V.; Varaprasad, K.; Madhukar, K. Antimicrobial Cellulose Nanocomposite Films with In Situ Generations of Bimetallic (Ag and $\mathrm{Cu}$ ) Nanoparticles Using Vitex negundo Leaves Extract. J. Inorg. Organomet. Polym. Mater. 2021, 31, 802-815. [CrossRef]

57. Bruna, T.; Maldonado-Bravo, F.; Jara, P.; Caro, N. Silver Nanoparticles and Their Antibacterial Applications. Int. J. Mol. Sci. 2021, 22, 7202. [CrossRef]

58. Mellinas, C.; Jiménez, A.; Garrigós, M.D.C. Microwave-Assisted Green Synthesis and Antioxidant Activity of Selenium Nanoparticles Using Theobroma Cacao L. Bean Shell Extract. Molecules 2019, 24, 4048. [CrossRef]

59. Kumar, S.V.; Bafana, A.P.; Pawar, P.; Faltane, M.; Rahman, A.; Dahoumane, S.A.; Kucknoor, A.; Jeffryes, C.S. Optimized production of antibacterial copper oxide nanoparticles in a microwave-assisted synthesis reaction using response surface methodology. Colloids Surf. A Physicochem. Eng. Asp. 2019, 573, 170-178. [CrossRef]

60. Ahmadi, O.; Jafarizadeh-Malmiri, H.; Jodeiri, N. Eco-friendly microwave-enhanced green synthesis of silver nanoparticles using Aloe vera leaf extract and their physico-chemical and antibacterial studies. Green Process. Synth. 2017, 7, 231-240. [CrossRef]

61. Hernández-Hernández, A.A.; Álvarez-Romero, G.A.; Castañeda-Ovando, A.; Mendoza-Tolentino, Y.; Contreras-López, E.; Galán-Vidal, C.A.; Páez-Hernández, M.E. Optimization of microwave-solvothermal synthesis of Fe3O4 nanoparticles. Coating, modification, and characterization. Mater. Chem. Phys. 2018, 205, 113-119. [CrossRef] 